\title{
Controlling the Global Mean Temperature by Decarbonization
}

\author{
Frits Mathias Dautzenberg ${ }^{1,{ }^{*}}$, Yong $\mathrm{Lu}^{2}$, Bin $\mathrm{Xu}^{3}$ \\ ${ }^{1}$ Serenix Corporation, 5632 Coppervein Street, Fort Collins, CO 80528, USA. \\ ${ }^{2}$ Shanghai Key Laboratory of Green Chemistry and Chemical Processes, School of Chemistry and Molecular Engineering, East \\ China Normal University, Shanghai 200062, China. \\ ${ }^{3}$ ECO Zhuo Xin Energy-Saving Technology (Shanghai) Company Limited, Shanghai 201109, China.
}

\begin{abstract}
Establishing a reliable method to predict the global mean temperature $\left(T_{\mathrm{e}}\right)$ is of great importance because $\mathrm{CO}_{2}$ reduction activities require political and global cooperation and significant financial resources. The current climate models all seem to predict that the earth's temperature will continue to increase, mainly based on the assumption that $\mathrm{CO}_{2}$ emissions cannot be lowered significantly in the foreseeable future. Given the earth's multifactor climate system, attributing atmospheric $\mathrm{CO}_{2}$ as the only cause for the observed temperature anomaly is most likely an oversimplification; the presence of water $\left(\mathrm{H}_{2} \mathrm{O}\right)$ in the atmosphere should at least be considered. As such, $T_{\mathrm{e}}$ is determined by atmospheric water content controlled by solar activity, along with anthropogenic $\mathrm{CO}_{2}$ activities. It is possible that the

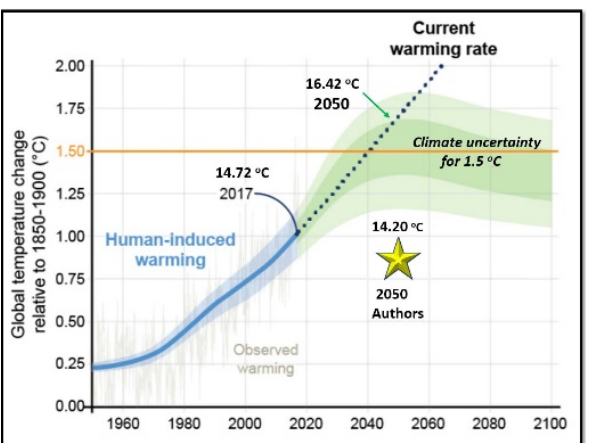
anthropogenic $\mathrm{CO}_{2}$ activities can be reduced in the future. Based on temperature measurements and thermodynamic data, a new model for predicting $T_{\mathrm{e}}$ has been developed. Using this model, past, current, and future $\mathrm{CO}_{2}$ and $\mathrm{H}_{2} \mathrm{O}$ data can be analyzed and the associated $T_{\mathrm{e}}$ calculated. This new, esoteric approach is more accurate than various other models, but has not been reported in the open literature. According to this model, by $2050, T_{e}$ may increase to $15.5^{\circ} \mathrm{C}$ under "businessas-usual" emissions. By applying a reasonable green technology activity scenario, $T_{\mathrm{e}}$ may be reduced to approximately $14.2^{\circ} \mathrm{C}$. To achieve $\mathrm{CO}_{2}$ reductions, the scenario described herein predicts a $\mathrm{CO}_{2}$ reduction potential of 513 gigatons in 30 years. This proposed scenario includes various $\mathrm{CO}_{2}$ reduction activities, carbon capturing technology, mineralization, and bio-char production; the most important $\mathrm{CO}_{2}$ reductions by 2050 are expected to be achieved mainly in the electricity, agriculture, and transportation sectors. Other more aggressive and plausible drawdown scenarios have been analyzed as well, yielding $\mathrm{CO}_{2}$ reduction potentials of 1051 and 1747 gigatons, respectively, in 30 years, but they may reduce global food production. It is emphasized that the causes and predictions of the global warming trend should be regarded as open scientific questions because several details concerning the physical processes associated with global warming remain uncertain. For example, the role of solar activities coupled with Milankovitch cycles are not yet fully understood. In addition, other factors, such as ocean $\mathrm{CO}_{2}$ uptake and volcanic activity, may not be negligible.
\end{abstract}

Key Words: Calculation method for global mean temperature; $\mathrm{CO}_{2}$ in the atmosphere; Water in the atmosphere; Global warming; $\mathrm{CO}_{2}$ reduction

Received: August 23, 2020; Revised: September 16, 2020; Accepted: September 18, 2020; Published online: September 21, 2020.

*Corresponding author. Email: fritsd@serenixcorp.com.

(C) Editorial office of Acta Physico-Chimica Sinica 


\title{
通过脱碳控制全球平均温度
}

\author{
Frits Mathias Dautzenberg ${ }^{1, *}$, 路勇 ${ }^{2}$, 徐涁 ${ }^{3}$ \\ ${ }^{1}$ Serenix Corporation, 5632 Coppervein Street, Fort Collins, CO 80528, USA. \\ 2 华东师范大学, 化学与分子工程学院, 上海市绿色化学与化工过程绿色化重点实验室, 上海 200062 \\ 3 易高卓新节能技术(上海)有限公司, 上海 201109
}

\begin{abstract}
摘要: 建立能可靠预测全球平均温度 $\left(T_{\mathrm{e}}\right)$ 的方法, 对于寻求政治和全球合作以及大量财政资源来推动 $\mathrm{CO}_{2}$ 减排至关重要。 基于可预见的若干年内 $\mathrm{CO}_{2}$ 排放量不能显著降低这一假设, 目前的气候模型似乎都预测 $T_{\mathrm{e}}$ 将会持续上升。然而, 将大气 中的 $\mathrm{CO}_{2}$ 作为多因素地球气候系统的唯一变量, 来关联观察到的温度异常, 很可能过于简单化了, 因为大气中 $\mathrm{H}_{2} \mathrm{O}$ 的存 在是至少应该要考虑的。受控于太阳活动的大气 $\mathrm{H}_{2} \mathrm{O}$ 含量是 $T_{\mathrm{e}}$ 的首要决定因素, 其次才是与人类活动相关的 $\mathrm{CO}_{2}$ 排放, 而 $\mathrm{CO}_{2}$ 排放将来可能降低。基于地球平均温度观测值和热力学数据, 建立了新的预测模型。应用该模型方程, 可以分析过去、 当前和未来大气中 $\mathrm{CO}_{2}$ 和 $\mathrm{H}_{2} \mathrm{O}$ 含量并可计算出相应的 $T_{\mathrm{e}}$ 。这是一个还未见公开报道的、更精确的模型。本模型预测, 依 据将较基准情景(business-as-usual, BAU), 到2050年 $T_{\mathrm{e}}$ 可能上升至 $15.5^{\circ} \mathrm{C}$; 通过合理的绿色技术行动方案, $T_{\mathrm{e}}$ 可能降 至约 $14.2^{\circ} \mathrm{C}$, 预测未来 30 年 $\mathrm{CO}_{2}$ 可减排 513 千兆吨。绿色技术应用场景包括诸如各种 $\mathrm{CO}_{2}$ 减排行动, 碳捕获, 矿化以及 生物碳生产等, 其中至2050年 $\mathrm{CO}_{2}$ 减排的主要贡献将来自于电力、农业和运输行业。另外, 也对更激进的Plausible和 Drawdown方案进行了分析, 预测未来30年 $\mathrm{CO}_{2}$ 可分别减排1051和1747千兆吨, 但这些方案可能会减少全球粮食生产。 要强调的是, 全球变暖的成因和预测应该视为开放的科学问题, 因为涉及与全球变暖相关的物理过程的多个问题仍然无解。 例如, 太阳活动耦合米兰科维奇(Milankovitch)循环扮演的角色就没有完全理解。还有, 海洋对 $\mathrm{CO}_{2}$ 的吸收和火山活动等 其他因素的影响，可能无法忽略。
\end{abstract}

关键词: 全球平均温度计算方法; 大气 $\mathrm{CO}_{2}$ 含量; 大气 $\mathrm{H}_{2} \mathrm{O}$ 含量；全球变暖； $\mathrm{CO}_{2}$ 减排 中图分类号: 0642

\section{Introduction}

Many climate models have been developed, based on mathematical computer simulations of many factors such as the temperature of the atmosphere, the oceans and the land surface and activities on the sun and other factors. These factors all interact and are important to determine the average mean world temperature $\left(T_{\mathrm{e}}\right)$ and other events related to the earth's climate. Many scientists legitimately have wondered how accurately these climate models can predict earth's future $T_{\mathrm{e}}$. A recent study by environmental scientists from Berkeley ${ }^{1}$ has shown that the climate models published during the past five decades have skillfully described $T_{\mathrm{e}}$ changes, with most examined models showing global temperature warming consistent with observations, particularly when mismatches between modelcalculated and observationally estimated were taken into account. Regarding the future $T_{\mathrm{e}}$, the current climate models all seem to predict that the earth's temperature will continue to increase mainly assuming that $\mathrm{CO}_{2}$ emissions cannot be lowered significantly in the foreseeable years.

In this paper, we will analyze observational data regarding global warming. Using readily available data, a simple calculation method for the $T_{\mathrm{e}}$ is proposed since other models published in the literature are not accurately predicting the future. This new proposed model should take into consideration the water in the atmosphere and anthropogenic $\mathrm{CO}_{2}$. The simple new model must also be consistent with thermodynamic calculations of the atmospheric energy balance. We also like to show how the earth's temperature may be decreased by certain reasonable $\mathrm{CO}_{2}$ reduction activities. Other climate change events not caused by the $T_{\mathrm{e}}$ have not be the objective of this paper.

\section{Data and methods}

\subsection{Global warming}

Fig. 1 shows the $T_{\mathrm{e}}$ (in blue) from 1850-2020. In brown, we indicate what the $T_{\mathrm{e}}$ would have been if the temperature increase were $0.0025^{\circ} \mathrm{C}$ per year, which was the case from 1600 till 2000, according to Table 1 . At this moment, the measured temperature is about $1{ }^{\circ} \mathrm{C}$ higher than the brown temperature. If this trend would continue (see Fig. 2), the $T_{\mathrm{e}}$ would be $16.4{ }^{\circ} \mathrm{C}$ by 2050 ,

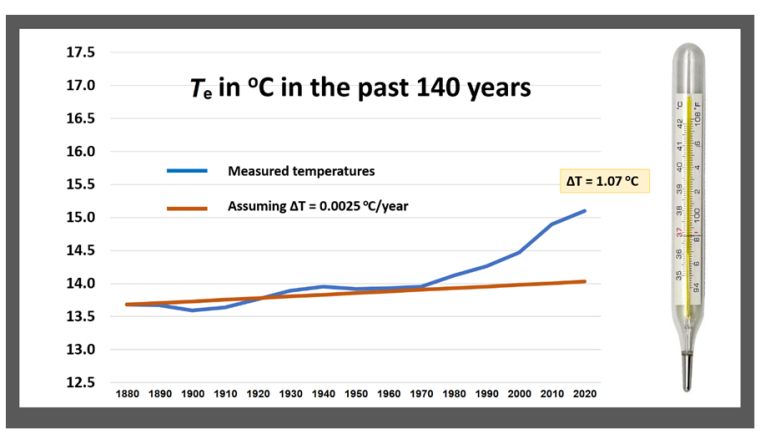

Fig. 1 The $T_{\mathrm{e}}$ in ${ }^{\circ} \mathrm{C}$ in the past 140 years, based on data from Refs. $2-4$. 
Table 1 Global temperature increase per year, including data from the National Aeronautics and Space Administration (NASA) and the Goddard Institute for Space Studies (GISS)

\begin{tabular}{lllll}
\hline & Years & $\Delta T$ & $\Delta T /$ year & $\Delta T / 100$ year \\
\hline Core Ice & 10000 & 11 & 0.0011 & 0.11 \\
$1600-2000$ & 400 & 1.0 & 0.0025 & 0.25 \\
$1910-2020$ & 110 & 1.4 & 0.0127 & 1.27 \\
$1980-2019$ & 39 & 0.9 & 0.0231 & 2.31 \\
\hline
\end{tabular}

Ref. 3 (NASA, GISS), Ref. 4 (Buis), Ref. 5 (Moore), Ref. 6 (Spencer), and Ref. 7 (Petit).

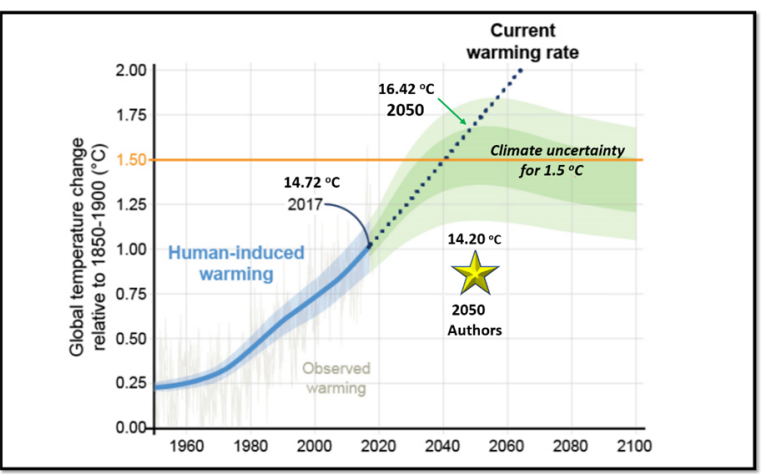

Adaptation of IPCC prediction and including Authors' estimate - see Section 3.3

Fig. 2 Expected global temperature change according to the IPCC $^{2}$ and the author's scenario.

and by 2100 , the $T_{\mathrm{e}}$ would be $19.0^{\circ} \mathrm{C}^{2}$. It becomes clear that the current global temperature increases of $0.0231{ }^{\circ} \mathrm{C} /$ year (from 1980 till 2019, see Table 1) is considerably higher than ever experienced on earth. However, we like to understand the causes of the observed increase of the $T_{\mathrm{e}}$, on a solid scientific basis.

\subsection{Global temperature as a function of water vapor and $\mathrm{CO}_{2}$ in the atmosphere}

The $T_{\mathrm{e}}$ is related to the amount of water in the atmosphere (largely controlled by solar irradiation ${ }^{8,9}$ ) and added $\mathrm{CO}_{2}$. The amount of $\mathrm{CO}_{2}$ in the atmosphere is currently measured daily. That has not been the case for water vapor in the atmosphere. However, data from the National Aeronautics and Space Administration (NASA) covering global precipitation (in $\mathrm{mm}$ per day) from 1900 till 2000 allow us to estimate the water content of the atmosphere since the residence of rain is known to be approximately 9 days.

Using the observed $\mathrm{CO}_{2}$ and water data of the earth's atmosphere in 1970 and 2019 and the measured $T_{\mathrm{e}}$ at those times (see Fig. 3), one can calculate two coefficients, one for water $a$ and one for $\mathrm{CO}_{2} b$ according to the following equation.

$$
T_{\mathrm{e}}\left(\text { in }{ }^{\circ} \mathrm{C}\right)=a \times\left[10^{-6}(\mathrm{v}) \mathrm{H}_{2} \mathrm{O}\right]+b \times\left[10^{-6}(\mathrm{v}) \mathrm{CO}_{2}\right]
$$

The experimental value of $a=2.696 \times 10^{-3}$ in ${ }^{\circ} \mathrm{C} /\left(10^{-6}(\mathrm{v})\right)$, while the value for $b=1.065 \times 10^{-2}$ in ${ }^{\circ} \mathrm{C} /\left(10^{-6}(\mathrm{v})\right)$.

Using thermodynamic data ${ }^{10,11}$, one can estimate the value of $a$ and $b$. For water, one uses the heat of formation of gaseous water, minus the heat of vaporization divided by the heat capacity $C_{\mathrm{p}}$ of liquid water to calculate the coefficient $a$ in ${ }^{\circ} \mathrm{C} /\left(10^{-6}(\mathrm{v})\right)$. Since $\mathrm{CO}_{2}$ is a gas at 13.95 and $15.10^{\circ} \mathrm{C}$, one

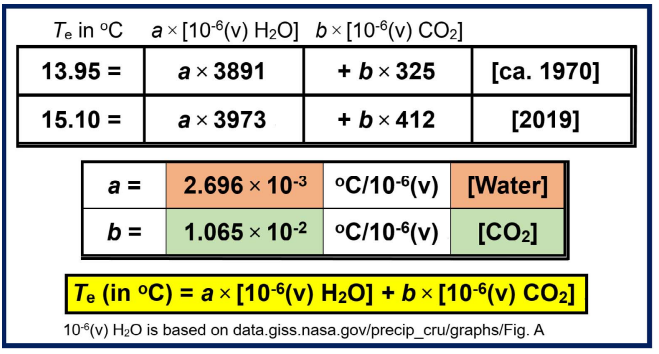

Fig. 3 Calculating $a$ and $b$ coefficients from experimental data.

only needs the heat of formation divided by heat capacity $C_{\mathrm{p}}$ for calculating $b$. The thermodynamic calculations for $\mathrm{H}_{2} \mathrm{O}$ and $\mathrm{CO}_{2}$ are shown in Table 2 and Table 3 . The $a$ and $b$ values using thermodynamics are close to the experimental data, with a delta of less than $2 \%$.

The value of $b$ can be used to establish the $\mathrm{CO}_{2}$ sensitivity as a function of $\mathrm{CO}_{2}$ increases in the atmosphere. Starting with a $\mathrm{CO}_{2}$ level is $280\left(\times 10^{-6}(\mathrm{v})\right)$ in 1870 and $410\left(\times 10^{-6}(\mathrm{v})\right)$ in 2019, the $\mathrm{CO}_{2}$ sensitivity becomes $\left(1.065 \times 10^{-2}\right) \times(410-280)=$ $1.38{ }^{\circ} \mathrm{C}$. If the $\mathrm{CO}_{2}$ doubled to $560\left(\times 10^{-6}(\mathrm{v})\right)$, the $\mathrm{CO}_{2}$ sensitivity would become $2.98{ }^{\circ} \mathrm{C}$, in line with recently reported data in the literature with values from $2.2-3.4{ }^{\circ} \mathrm{C}{ }^{12}$. On this basis, we estimated that the $\mathrm{CO}_{2}$ in the atmosphere should not pass beyond $440\left(\times 10^{-6}(\mathrm{v})\right)$ by 2050 if one aims at a maximum temperature increase of $1.5^{\circ} \mathrm{C}$ in the future. It will be shown in Section 3.2 how this stringent objective is achievable.

Table 2 Thermodynamic calculations * of $a$ coefficient.

\begin{tabular}{cccccc}
\hline$T /{ }^{\circ} \mathrm{C}$ & $T / \mathrm{K}$ & $\Delta H_{\mathrm{f}} /\left(\mathrm{kJ} \cdot \mathrm{mol}^{-1}\right)$ & $\Delta H_{\text {vap }} /\left(\mathrm{kJ} \cdot \mathrm{mol}^{-1}\right)$ & $C_{\mathrm{p}} /\left(\mathrm{kJ} \cdot \mathrm{mol}^{-1} \cdot \mathrm{K}^{-1}\right)$ & $a /{ }^{\circ} \mathrm{C} /\left(10^{-6}(\mathrm{v})\right)$ \\
\hline 25.00 & 298.15 & -241.89 & 44.54 & 0.07537 & $2.6182 \times 10^{-3}$ \\
13.50 & 286.65 & -242.27 & 43.98 & 0.07560 & $2.6227 \times 10^{-3}$ \\
13.95 & 287.10 & -242.25 & 44.01 & 0.07559 & $2.6226 \times 10^{-3}$ \\
14.50 & 287.65 & -242.23 & 44.03 & 0.07558 & $2.6225 \times 10^{-3}$ \\
15.10 & 288.25 & -242.21 & 44.06 & 0.07556 & $2.6224 \times 10^{-3}$ \\
15.50 & 288.65 & -242.20 & 44.08 & 0.07555 & $2.6223 \times 10^{-3}$ \\
16.00 & 289.15 & -242.18 & 44.10 & 0.07554 & $2.6221 \times 10^{-3}$ \\
16.50 & 289.65 & -242.17 & 44.13 & 0.07553 & $2.6220 \times 10^{-3}$ \\
17.00 & 290.15 & -242.15 & 44.15 & 0.07552 & $2.6219 \times 10^{-3}$ \\
\hline
\end{tabular}

"Thermodynamic data in Refs. 10, 11.

Table 3 Thermodynamic calculations * of $b$ coefficient.

\begin{tabular}{ccccc}
\hline$T /{ }^{\circ} \mathrm{C}$ & $T / \mathrm{K}$ & $\Delta H_{f} /\left(\mathrm{kJ} \cdot \mathrm{mol}^{-1}\right)$ & $C_{\mathrm{p}} /\left(\mathrm{kJ} \cdot \mathrm{mol}^{-1} \cdot \mathrm{K}^{-1}\right)$ & $b /{ }^{\circ} \mathrm{C} /\left(10^{-6}(\mathrm{v})\right)$ \\
\hline 13.50 & 286.65 & -393.95 & 37.40 & $1.0532 \times 10^{-2}$ \\
13.95 & 287.10 & -393.93 & 37.42 & $1.0526 \times 10^{-2}$ \\
14.50 & 287.65 & -393.91 & 37.45 & $1.0519 \times 10^{-2}$ \\
15.10 & 288.25 & -393.89 & 37.47 & $1.0511 \times 10^{-2}$ \\
15.50 & 288.65 & -393.88 & 37.49 & $1.0506 \times 10^{-2}$ \\
16.00 & 289.15 & -393.86 & 37.51 & $1.0499 \times 10^{-2}$ \\
16.50 & 289.65 & -393.84 & 37.53 & $1.0493 \times 10^{-2}$ \\
17.00 & 290.15 & -393.82 & 37.56 & $1.0486 \times 10^{-2}$ \\
\hline \multicolumn{5}{c}{ Thermodynamic data in Refs. 10, 11. } \\
\hline
\end{tabular}




\section{Results}

\subsection{Past and future global temperatures using Eq.}

(1)

In many cases, one measured the $T_{\mathrm{e}}$ and the $\mathrm{CO}_{2}$ in $10^{-6}(\mathrm{v})$. Fig. 4 shows data for $\mathrm{CO}_{2}, \mathrm{H}_{2} \mathrm{O}$, and associated $T_{\mathrm{e}}$ from 1880 till 2019, using Eq. (1). The observed $\mathrm{CO}_{2}$ and $\mathrm{H}_{2} \mathrm{O}$ data of 1970 and 2019 were used to establish the $a$ and $b$ coefficients, as discussed in Section 2.2. The $\mathrm{CO}_{2}$ did increase from $280(\times$ $\left.10^{-6}(\mathrm{v})\right)$ in 1880 to $410\left(\times 10^{-6}(\mathrm{v})\right)$ in 2019 (see Fig. 4). The concentration of $\mathrm{H}_{2} \mathrm{O}$ in the atmosphere varied slightly during this period, which is possibly a natural trend ${ }^{13}$, depending on the absorbed solar radiation. This indicates that, on average, $71 \%$ of the observed $T_{\mathrm{e}}$ is caused by $\mathrm{H}_{2} \mathrm{O}$ in the atmosphere, while $\mathrm{CO}_{2}$ contributes $29 \%$.

From 1980 to 2019 , the delta $T_{\mathrm{e}}$ increased from $0.50{ }^{\circ} \mathrm{C}$ to $1.44{ }^{\circ} \mathrm{C}$, relative to maintaining $\mathrm{CO}_{2}$ at $280\left(\times 10^{-6}(\mathrm{v})\right)$, as in 1870. The delta $T_{\mathrm{e}}$ increase due to higher $\mathrm{CO}_{2}$ was, therefore, $0.024{ }^{\circ} \mathrm{C}$ per year from 1980 to 2019 (see Table 1), which is an alarming increase, according to the authors of the Intergovernmental Panel on Climate Change (IPCC) reports ${ }^{2}$.

As shown in references ${ }^{14-17}$, the earth's temperatures in the past have been significantly higher than the current $T_{\mathrm{e}}$, while the levels of $\mathrm{CO}_{2}$ have been higher as well as lower than the current $\mathrm{CO}_{2}$ level at $410\left(\times 10^{-6}(\mathrm{v})\right)$ (see Fig. 5). We, therefore, conclude that there is no clear correlation between the $T_{\mathrm{e}}$ of the earth and the $\mathrm{CO}_{2}$ in the atmosphere, as noted by other scientists as well ${ }^{6,18}$.

In 1998, 24.4 gigatons of $\mathrm{CO}_{2}$ was added to the atmosphere, increasing to 36.6 gigatons in $2018{ }^{19}$. As a result, the atmosphere contained 3120 gigatons $\mathrm{CO}_{2}$ in 1998 and 3450 gigatons in 2018. That corresponds to a $\mathrm{CO}_{2}$ residence time of about 30 years, in line with various papers in the literature, e.g., Ref. 20. Consequently, only a fraction of the emitted $\mathrm{CO}_{2}$ remains in the atmosphere (equal to 0.918), while the remaining $\mathrm{CO}_{2}$ will be absorbed by oceans, seas, and land, including photosynthesis activities.

\subsection{Approaches to decrease $\mathrm{CO}_{2}$ in the atmosphere}

Using a similar approach for calculating the $\mathrm{CO}_{2}$ in the atmosphere from 1998 till 2018 (see Section 3.1) and applying a "business-as-usable" scenario, we estimate that the $T_{\mathrm{e}}$ could be

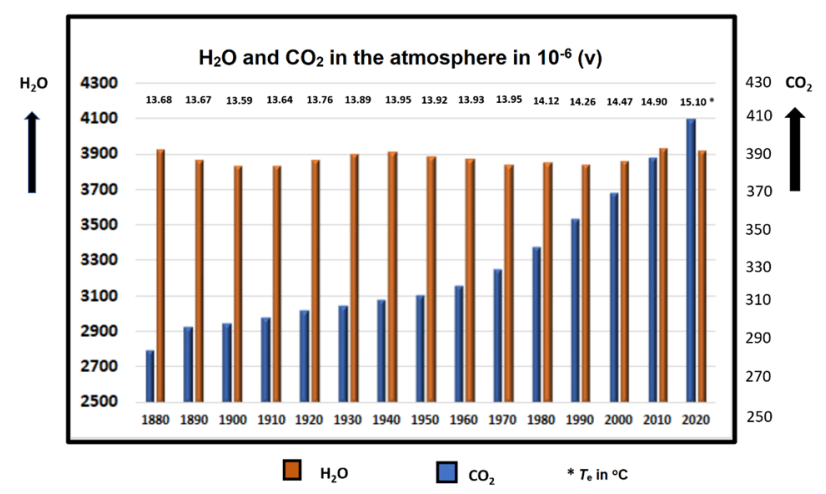

Fig. $4 \mathrm{CO}_{2}$ and $\mathrm{H}_{2} \mathrm{O}$ in the atmosphere and associated $T_{\mathrm{e}}$ from 1880 till 2019.
Global temperatures $\left(T_{\mathrm{e}}\right)$ plus $\mathrm{H}_{2} \mathrm{O}$ and $\mathrm{CO}_{2}$ atmospheric concentrations

\begin{tabular}{|c|c|c|c|c|c|c|c|}
\hline Past & $\mathrm{H}_{2} \mathrm{O}$ & $\mathrm{CO}_{2}$ & Total & Current & $\mathrm{H}_{2} \mathrm{O}$ & $\mathrm{CO}_{2}$ & Total \\
\hline$T_{\mathrm{e}}$ in ${ }^{\circ} \mathrm{C}$ & 17.5 & 3.1 & 20.6 & $T_{\mathrm{e}}$ in ${ }^{\circ} \mathrm{C}$ & 10.6 & 4.5 & 15.1 \\
\hline $10^{-6}(v)$ & 6535 & 280 & \multirow{3}{*}{$\begin{array}{c}\text { History } \\
\text { many years } \\
\text { ago }^{\star}\end{array}$} & $10^{-6}(\mathrm{v})$ & 3981 & 410 & \multirow{3}{*}{2019} \\
\hline $10^{-6}$ (wt) & 4083 & 428 & & $10^{-8}(\mathrm{wt})$ & 2449 & 626 & \\
\hline Gigaton & 22496 & 2356 & & Gigaton & 13494 & 3450 & \\
\hline Past & $\mathrm{H}_{2} \mathrm{O}$ & $\mathrm{CO}_{2}$ & Total & Future & $\mathrm{H}_{2} \mathrm{O}$ & $\mathrm{CO}_{2}$ & Total \\
\hline$T_{\mathrm{e}}$ in ${ }^{\circ} \mathrm{C}$ & 9.5 & 4.1 & 13.6 & $T_{\mathrm{e}}$ in ${ }^{\circ} \mathrm{C}$ & 10.0 & 4.3 & 14.3 \\
\hline $10^{-6}(\mathrm{v})$ & 3876 & 295 & \multirow{3}{*}{1900} & $10^{-6}(\mathrm{v})$ & 3921 & 351 & \multirow{3}{*}{$\begin{array}{c}\text { Author } \\
\text { Scenario } \\
2050+\end{array}$} \\
\hline $10^{-6}(w t)$ & 2431 & 452 & & $10^{-6}(\mathrm{wt})$ & 2427 & 538 & \\
\hline Gigaton & 13397 & 2493 & & \begin{tabular}{|l|} 
Gigaton \\
\end{tabular} & 13374 & 2967 & \\
\hline
\end{tabular}

Fig. $5 \mathrm{CO}_{2}$ and $\mathrm{H}_{2} \mathrm{O}$ in the atmosphere and associated $T_{\mathrm{e}}$ in the past, current and future.

$15.5^{\circ} \mathrm{C}$ by 2050 and about $17.0^{\circ} \mathrm{C}$ by 2100 , extrapolating the $T_{\mathrm{e}}$ increased from $1980-2019$ by $0.0231{ }^{\circ} \mathrm{C} /$ year (see Table 1). These $T_{\mathrm{e}}$ estimates are lower than mentioned above in section 2.1 based on IPCC data, but it is more important that we agree with many scientists that everything should be done to keep the $T_{\mathrm{e}}$ increase at about $1.5-2.0{ }^{\circ} \mathrm{C}$, including most of the participants of the IPCC ${ }^{2}$. However, it is well known that not everybody agrees with the IPCC objective (see, e.g., Refs. 5, 6, 18,21 as typical examples).

The most effective way to manage anthropologic $\mathrm{CO}_{2}$ emissions is to avoid the formation of $\mathrm{CO}_{2}$. Furthermore, carbonneutral technologies may assist in greening the world. Also, photosynthesis is an essential natural method to reduce $\mathrm{CO}_{2}$ from the atmosphere, and technologies that remove $\mathrm{CO}_{2}$ from the atmosphere may also become viable in the future. In the following paragraphs, we will present summaries of what can be achieved.

\subsubsection{Electrical power generation}

It is apparent that $\mathrm{CO}_{2}$ reduction options for electrical power generation are being pursued around the world. By 2050, we estimate that 215 gigatons of $\mathrm{CO}_{2}$ can be avoided mainly by applying wind and solar technology.

\subsubsection{Agriculture including forestry}

$\mathrm{CO}_{2}$ reduction in the agriculture sector is also possible ${ }^{22,23}$. In the next 30 years 471.5 gigatons of $\mathrm{CO}_{2}$ emissions could be avoided. Forestry management, new agriculture technologies, and reducing food waste are likely the key areas with the most significant impact. Around the world, large scale reforestation projects are in progress, like in China, Brazil, USA, Morocco, and other countries

\subsubsection{Building}

Better maintenance of air conditioning equipment could potentially reduce $\mathrm{CO}_{2}$ emissions by 89.4 gigatons between 2020 and 205022 . Additionally, another 54.5 gigatons $\mathrm{CO}_{2}$ reductions are possible using, for instance, district heating, better insulation, and LED lighting.

\subsubsection{Transportation}

The transportation sector can potentially reduce $\mathrm{CO}_{2}$ emissions by 134 gigatons during the period from 2020 to 2050 . This may be achieved using a variety of technologies. Around 
the world, hydrogen fueled cars, electric cars, hybrid cars and mass transportation are already actively pursued and improved ships, trucks, and airplanes will follow as well. Biomass can be converted to transportation fuels, enabling carbon neutral recycling ${ }^{24,25}$.

\subsubsection{Industry}

In the industry sector, fuels, and chemicals from sustainable resources ${ }^{24}$ can lead to reductions in $\mathrm{CO}_{2}$ emissions. Biomass, municipal solid waste, and other carbon-containing streams can be used to produce bio-SNG, bio-jet fuel, green methanol, and green ammonia 25 . It may take some time to transform the industry sector to greener technologies, but several companies are already working on this.

\subsubsection{Other $\mathrm{CO}_{2}$ reduction methods}

Education and family planning are highlighted to reverse the global temperature increase ${ }^{25}$, reducing $\mathrm{CO}_{2}$ emissions by 109.2 Gigatons during the next 30 years. One hopes that with education and family planning, the total world population will not increase as fast as projected.

In addition to the methods reviewed above, one can remove $\mathrm{CO}_{2}$ from the atmosphere to lower the $T_{\mathrm{e}}$. The following approaches may be suitable.

\subsubsection{Photosynthesis}

Photosynthesis is a natural way to remove $\mathrm{CO}_{2}$ from the atmosphere. This requires that the atmosphere contains at least $150\left(\times 10^{-6}(\mathrm{v})\right) \mathrm{CO}_{2}$ with an optimum $\mathrm{CO}_{2}$ level of $1500(\times$ $\left.10^{-6}(\mathrm{v})\right)$. For this reason, farmers and gardeners add $\mathrm{CO}_{2}$ to their greenhouses.

\subsubsection{Biochar}

Biochar is an emerging carbon material derived from renewable resources. This has triggered great interest in a variety of areas, including carbon sequestration and potential soil amendments ${ }^{26}$. Trees and plants do grow faster in sandy soil mixed with clay, biochar, and mycorrhizae fungi if one has enough water. This had been demonstrated successfully, for instance, in the Gobi Desert in China and around the Sahara for the Great Green Wall initiative.

\subsection{9 $\mathrm{CO}_{2}$ mineralization}

To date, the most widely accepted method of carbon capture and storage (CCS) is the injection of $\mathrm{CO}_{2}$ into underground geological formations and reservoirs. However, the risk remains that potentially suitable reservoirs may turn out to be insufficient, uneconomic, or impractical ${ }^{27}$.

Carbon capture and mineral carbonation (CCMC), also called $\mathrm{CO}_{2}$ mineralization, has been identified by the IPCC as a possible promising additional technology to remove $\mathrm{CO}_{2}$ from the atmosphere. CCMC is a process whereby $\mathrm{CO}_{2}$ is chemically reacted with calcium- and/or magnesium-containing minerals to form stable carbonate materials which do not incur any longterm liability or monitoring commitments. CCMC is highly verifiable and permanent in nature. Companies are pursuing CCMC, and demonstration pilot plants have already been in operation ${ }^{28}$. Australia recently discovered large deposits of halloysite-kaolin clay that can be used for CCMC ${ }^{29}$.

\subsubsection{Direct air capture of $\mathrm{CO}_{2}$}

Biochar plus $\mathrm{CO}_{2}$ mineralization can potentially remove about 78 gigatons of $\mathrm{CO}_{2}$ in 30 years, as estimated in Ref. 22. By 2050, direct air capture of $\mathrm{CO}_{2}$ could become an additional viable technology, if the captured $\mathrm{CO}_{2}$ is used for CCS and/or CCMC.

\subsubsection{Geoengineering}

Star Technology and Research ${ }^{30}$ has designed a system of space mirrors that blocks sunlight from reaching the earth and provides another source of clean energy for the earth. These spacecraft mirrors are remotely controlled and equipped with solar panels that collect some of the sunlight and send the captured energy back down to earth. However, geoengineering has many potential pitfalls that have not made it popular with scientists, whose climate platforms focus instead on ways to reduce the earth away from fossil fuels ${ }^{31}$.

\subsection{Applying scenarios to reduce $\mathrm{CO}_{2}$ emissions}

Five scenarios have been developed (see Fig. 6), using similar calculations to assess the $\mathrm{CO}_{2}$ in the atmosphere from 1998 to 2018, shown in Section 3.2. The first scenario, called "Businessas-usable" (BAU), extrapolates the current $\mathrm{CO}_{2}$ emissions data ${ }^{13}$ until 2050, leading to an increase of 531 gigatons $\mathrm{CO}_{2}$ in the atmosphere. The Shell scenario ${ }^{32}$ is a little better than the BAU scenario but still increases the $\mathrm{CO}_{2}$ in the atmosphere of 351 gigatons. The most aggressive scenarios are called "Plausible" and "Drawdown" based on Ref. 22. The input of 192 well-known environmental experts, scientists, engineers, architects, lawyers

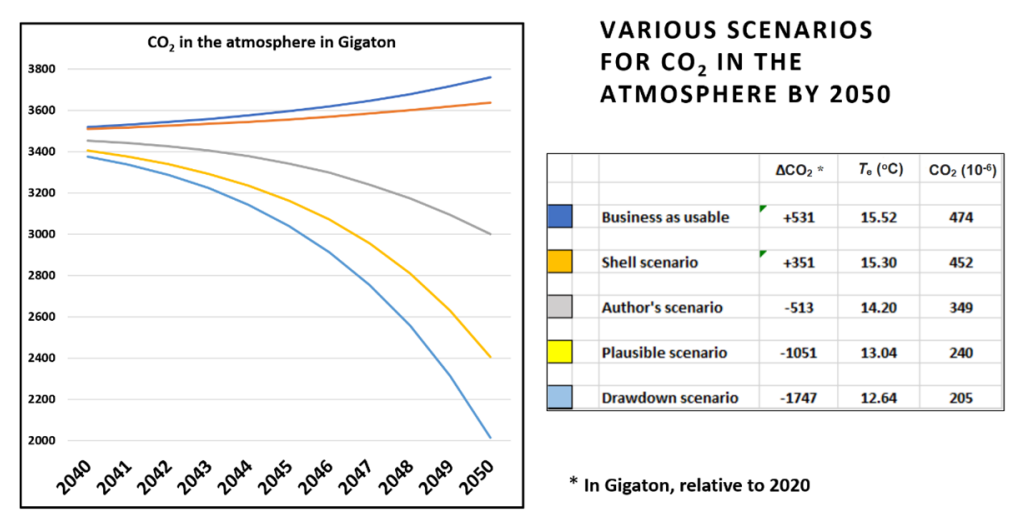

Fig. 6 Various scenarios for $\mathrm{CO}_{2}$ in the atmosphere by 2050 . 


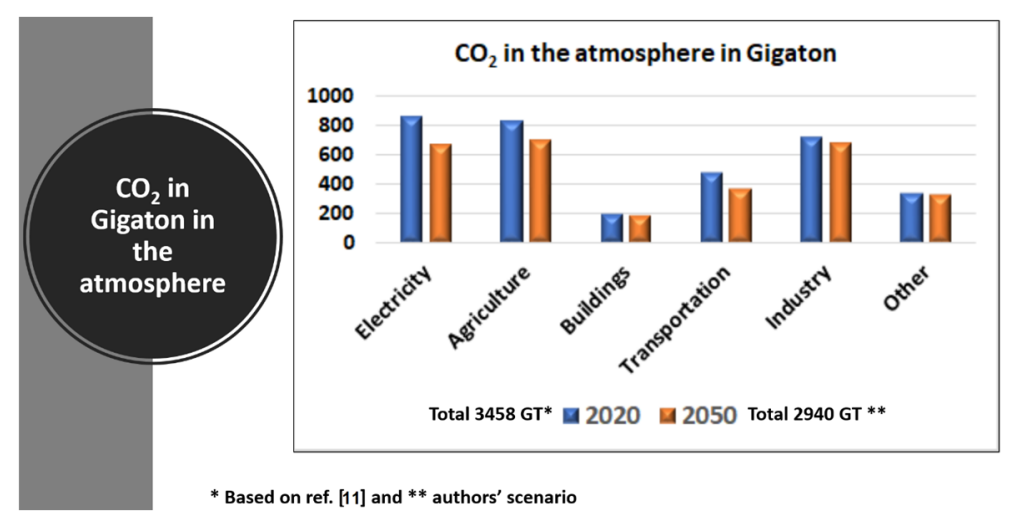

Fig. $7 \mathrm{CO}_{2}$ in gigaton in the atmosphere, based on authors' scenario and data from Ref. 11.

and writers have contributed to the formulation of the Plausible and Drawdown scenarios. The Plausible scenario is an optimistic, feasible frame work and forecast of $\mathrm{CO}_{2}$ reduction activities that could impact the global climate with a total $\mathrm{CO}_{2}$ reduction of 1051 gigatons in 30 years. The Drawdown scenario describes the most comprehensive plan to reverse global warming. It shows what would happen when the more conservative assumptions of the Plausible scenario are removed. In this case, a total $\mathrm{CO}_{2}$ reduction of 1747 gigatons in 30 years could be realized. The proposed authors' scenario is selected as an achievable compromise approach, predicting $\mathrm{a}_{2}$ reduction potential of 513 gigatons. Fig. 6 also lists corresponding global $T_{\mathrm{e}}$ in ${ }^{\circ} \mathrm{C}$ and the expected $\mathrm{CO}_{2}$ in $10^{-6}(\mathrm{v})$. The Plausible and the Drawdown scenarios would affect global food production since the $\mathrm{CO}_{2}$ would drop to $240\left(\times 10^{-6}(\mathrm{v})\right)$ and $205\left(\times 10^{-6}(\mathrm{v})\right)$, lower than in 1850 .

The anthropologic $\mathrm{CO}_{2}$ emission in 2020 is estimated to lead to 3458 gigatons of $\mathrm{CO}_{2}$ in the atmosphere, applying the trends shown on Ref. 19. According to the author's scenario, the $\mathrm{CO}_{2}$ in the atmosphere would reduce to 2945 gigatons. The distribution of this amount by sectors of activity is shown in Fig. 7. The data indicates that relative to 2020 , the most important $\mathrm{CO}_{2}$ reductions by 2050 are expected to be achieved mainly in the electricity, agriculture, and transportation sectors.

\section{Conclusion and discussion}

It is a fact that the mean temperature of the earth has been increasing slightly during the past 60 years, which is supported by numerous data. Referring to Section 3.1, the $a$ and $b$ coefficients are based on observational data such as the $T_{\mathrm{e}}$, the $\mathrm{CO}_{2}$ in the atmosphere, and water in the atmosphere derived from rainfall records. The thermodynamic calculated $a$ and $b$ coefficients are in line with the experimental values. Furthermore, the $0.918 \mathrm{CO}_{2}$ decrease rate per year used in Section 3.1 shows that $\mathrm{CO}_{2}$ remains in the atmosphere for many years, while water in the atmosphere only stays about 9 days. The amount of water in the atmosphere is, however, more dominant in terms of the earth's temperature than the contribution of $\mathrm{CO}_{2}$. The amount of water hardly changed from 1850 till 2020, independent of the increasing $\mathrm{CO}_{2}$ amount. Fig.
2 illustrates the expected $T_{\mathrm{e}}$ according to the IPCC ${ }^{2}$ and the author's scenario. If "Business as usable" is happening, the IPCC projects that the $T_{\mathrm{e}}$ could increase to $16.4^{\circ} \mathrm{C}$ by 2050 . Applying the correlations describes in Section 3.2, we estimate that the $T_{\mathrm{e}}$ may increase to $15.5^{\circ} \mathrm{C}$ for a "Business as usable" scenario. According to the author's scenario, a $T_{\mathrm{e}}$ of $14.2^{\circ} \mathrm{C}$ seems to be achievable by 2050 . Using the proposed simple model to calculate $T_{\mathrm{e}}$ may seem to be an oversimplification, since it does not predict other important climate events, which were not part of the paper's objective.

Indeed, several questions regarding physical processes associated with global warming remain unanswered. That means that the causes and prediction of the global warming trend should be considered as open scientific questions. For instance, the roles of sun activities coupled with Milankovitch cycles, are not fully understood yet. Also, other factors like ocean $\mathrm{CO}_{2}$ uptake and volcanic activities, may not be negligible.

Basing the multi-factor earth's climate system to $\mathrm{CO}_{2}$ in the atmosphere as the only variable causing the observed temperature anomaly is most likely an oversimplification, because one should at least consider the presence of water in the atmosphere. That does not mean that efforts to lower $\mathrm{CO}_{2}$ emissions should not be pursued because getting to a fossil-free world is ultimately unavoidable and will create progress in many ways.

Conflict of interest: The authors declare that they have no conflict of interest.

\section{References}

(1) Hausfather, Z.; Drake, H. F.; Abott, T.; Schmidt, G. A. Geophys. Res Lett. 2020, 47 (1), e2019GL085378. doi: 10.1029/2019GL085378

(2) Intergovernmental Panel on Climate Change (IPCC) Reports, 1990 2019. https://www.ipcc.ch (accessed on Sep. 18, 2020).

(3) GISS Surface Temperature Analysis (GISTEMP v4), version 4, 2019. https://data.giss.nasa.gov/gistemp (accessed on Sep. 18 2020).

(4) Buis, A. Study conforms climate models are getting future warming projections right. https://climate.nasa.gov/news/2943/study-confirms- 
climate-models-are-getting-future-warming-projections-right/ (accessed on Sep. 18 2020).

(5) Moore, P. A. Confessions of a Greenpeace Dropout; Beatty Street Publishing Inc.: Vancouver, BC, Canada, 2013.

(6) Spencer, R. W. The Greatest Global Warming Blunder: How Mother Nature Fooled the World's Top Climate Scientists; Encounter Books: New York, NY, USA, 2010.

(7) Petit, J. R.; Jouzel, J.; Raynaud, D.; Barkov, N. I.; Barnola, J. -M.; Basile, I.; Bender, M.; Chappellaz, J.; Davis, M.; Delaygue, G.; et al. Nature 1999, 399 (6735), 429. doi: 10.1038/20859

(8) Bohren, C. F.; Clothiaux, E. E. Fundamentals of Atmospheric Radiation: An Introduction with 400 Problems; Wiley-VCH Verlag GmbH \& Co. KGaA: Weinheim, Germany, 2006

(9) www.geo.utexas.edu/courses/387H/Lectures/chap2.pdf (accessed on Sep. 18 2020).

(10) https://www.nist.gov/publications/web-thermo-tables-line-versiontrc-thermodynamics-table (accessed on Sep. 18, 2020).

(11) Yaws, C. L. Chemical Properties Handbook; McGraw-Hill: New York, NY, USA, 1999; p. 291 and p. 310.

(12) Cox, P. M.; Huntingford, C.; Williamson, M. S. Nature 2018, 533 (7688), 319. doi: 10.1038/nature25450

(13) Deser, C. Making Sense of Climate Projections. Lecture at the University of Washington, Department of Atmospheric Sciences: Seattle, WA, USA, 2019.

(14) http://www.scotese.com/earth.htm. (accessed on Sep. 18 2020)

(15) Ruddiman, W. F. Earth's Climate: Past and Future, 3rd ed.; W.H. Freeman \& Sons: New York, NY, USA, 2013.

(16) Pagani, M.; Zachos, J. C.; Freeman, K. H.; Tipple, B.; Bohaty, S. Science 2005, 309 (5734), 600. doi: 10.1126/science.1110063

(17) https://www.sciencemag.org/news/2019/05/500-million-year-surveyearths-climate-reveals-dire-warning-humanity (accessed on Sep. 18 2020).

(18) Moore, P. A. Climate Realism. Presentation at the Climate Realism seminar, Toronto, Canada, October, 2019.

(19) https://ourworldindata.org/ $\mathrm{CO}_{2}$-and-other-greenhouse-gas-emissions (accessed on Sep. 18, 2020).

(20) Abbot, J.; Marohasy, J. Geo. Res. J. 2017, 14, 36. doi: 10.1016/j.grj.2017.08.001

(21) https://www.therightinsight.org/Patrick-Moore-Should-WeCelebrate- $\mathrm{CO}_{2}$ (accessed on Sep. 18, 2020).

(22) Hawken, P. Drawdown-The Most Comprehensive Plan Ever Proposed to Reverse Global Warming; Penguin Books, New York, NY, USA, 2017

(23) Henson, R. The Thinking Person's Guide to Climate Change, 2nd ed.; The American Meteorological Society: Boston, MA, USA, 2019.

(24) Vertes, A.; Qureshi, N.; Yukawa, H.; Blaschek, H. Biomass to Biofuels: Strategies for Global Industries. John Wiley \& Sons LTD.: Chicher, West Sussex, UK, 2010.

(25) Anastassiadis, S. G. World J. Bio. Biotechnol. 2016, 1 (1), 1. doi: $10.33865 /$ wjb.001.01.0002

(26) Han, L.; Ro, K. S; Sun, K.; Sun, H.; Wang, Z.; Libra, J. A.; Xing, B. Environ. Sci. Technol. 2016, 50 (24), 13274. doi: 10.1021/acs.est.6b02401

(27) Doucet, F. J. Scoping Study on $\mathrm{CO}_{2}$ Mineralization Technologies. Report No. CGS-2011-007-Prepared for South African Centre for Carbon Capture and Storage, 2011.

(28) Xie, H.; Yue, H.; Zhu, J.; Liang, B.; Li, C.; Wang, Y.; Xie, L.; Zhou, X. Engineering 2015, 1 (1), 150. doi: 10.15302/J-ENG-2015017

(29) https://www.theleadsouthaustria.com.au, Willis, B. Global carbon capture potential for rare nanoparticles, 2020, March 24 (accessed on Sep. 18, 2020).

(30) Dean, C. Expert Discuss Engineering Feats, Like Space Mirrors to Slow Climate Change; The New York Times: New York, NY, USA, Nov. 10, 2007.

(31) Gramling, C. In a Climate Crisis, Is Geoengineering Worth the Risks? Science News; Society for Science \& the Public: Washington DC, USA, Oct. 6, 2019.

(32) www.shell.com/energy-and-innovation/the-energyfuture/scenarios/shell-scenario-sky.html (accessed on Sep. 18, 2020). 